\title{
MUHAMMAD SEBAGAI PEMIMPIN AGAMA DAN NEGARA PERIODE MAKKAH DAN MADINAH
}

\author{
Vmmu Zakiyah Maulidah \\ UIN Sunan Ampel Surabaya \\ Email: zazakieyach@gmail.com
}

\begin{abstract}
Muhammad was born in Mecca between AD 570 and 580 in the Banu Hashims, a reputable family of Quraysh. In Mecca, Muhammad is portrayed as a private citizen, as he had to limit himself and adapt his behavior to face the situation during jahiliyyah era. While, in Medina he governed the community and guided them in religious life. His arrival in Medina has significant contribution toward his role as political leader. His power in this city had protected himself and his followers from violent opposition of the Quraysh. The doctrines he employed in politics were inseparable from the religious values rooted from the Quran. Through his innovation and skillful diplomacy, he had converted the people of Mecca and Medina into brighter Arab civilization. Such a positive change reflected his monumental accomplishment for the people.

Muhammad lahir di kota Makkah antara tahun 570 sampai 580 Masehi di keluarga Bani Hasyim, suku Quraisy terkemuka di Arab. Di kota Makkah, Muhammad dianggap sebagai masyarakat biasa, sebab ia harus membatasi dirinya dan menyesuaikan prilakunya dalam menghadapi keadaan yang terjadi pada zaman jahiliyyah. Sedangkan di Madinah, ia dianggap sebagai pemimpin masyarakat dan menjadi pembimbing umat dalam hidup beragama. Kedatangannya di Madinah juga memberikan konstribusi besar pada perannya sebagai pemimpin politik. Kekuasaan di kota ini sangat membantu dirinya dan para pengikutnya dari kerasnya kelompok oposisi Quraisy. Doktin-doktrin yang digunakan Muhammad dalam dunia politik juga tidak lepas dari nilai-nilai agama yang bersumber dari al Quran. Dengan kreatifitas dan inovasinya dalam memimpin, Muhammad mampu mengarahkan masyarakat Makkah dan
\end{abstract}


Madinah menuju kebangkitan peradaban bangsa Arab yang lebih cemerlang. Kondisi yang semakin membaik tersebut, tidak lain merupakan sebuah karya dan jasa monumental yang telah diukir oleh Muhammad untuk umatnya.

Keywords: Muhammad, Islam, politics, Mecca, Medina

\section{Pendahuluan}

Abad ke-4 sampai ke-6 sesudah Masehi (Late Sasanid and Primitive Caliphal Periods/Periode Sasani Akhir dan Khilafah Awal yakni tahun 485-692) merupakan salah satu abad terpenting dalam sejarah dan sangat mempengaruhi kondisi kehidupan manusia saat ini. Pada abad ini dimulailah pembentukan doktrin-doktrin Islam, pembentukan masyarakat Islam, penyebaran Islam di sekitar Jazirah Arabia, perluasan wilayah dan pengaruh politik Islam (Hodgson, 2000: 137).

Berikut Hodgson meringkas periodesasi ikhtisar sejarah dunia Islam:

\begin{tabular}{|l|l|}
\hline Tahun & Periode \\
\hline $485-692$ & $\begin{array}{l}\text { Periode Sasani akhir dan Khilafah awal } \\
\text { (Campur tangan Islam ke dalam masyarakat Irano-Semitik } \\
\text { dan munculnya sebuah tatanan sosial baru) }\end{array}$ \\
\hline $692-945$ & $\begin{array}{l}\text { Periode Kekhalifahan tertinggi } \\
\text { (Sebuah peradaban klasik dibawah kekuasaan Bani Marwan } \\
\text { dan Kekhalifahan Abbasiyah awal) }\end{array}$ \\
\hline $945-1258$ & $\begin{array}{l}\text { Periode Islam Pertengahan awal } \\
\text { (Berdirinya sebuah peradaban internasional yang menyebar } \\
\text { ke luar batas wilayah Irano-Semitik) }\end{array}$ \\
\hline $1258-1503$ & $\begin{array}{l}\text { Periode Islam Pertengahan } \\
\text { (Masa prestis Mongol, krisis dan pembaharuan dalam } \\
\text { lembaga-lembaga dan warisan yang bercorak Islam) }\end{array}$ \\
\hline
\end{tabular}




\begin{tabular}{|l|l|}
\hline $1503-1789$ & $\begin{array}{l}\text { Periode Kekaisaran Gunpouder } \\
\text { (Perkembangan kebudayaan bercorak Persia dibawah } \\
\text { kekaisaran regional utama) }\end{array}$ \\
\hline 1789 - sekarang & $\begin{array}{l}\text { Masa Modern } \\
\text { (Warisan Islam tertinggi modern/dunia baru) }\end{array}$ \\
\hline
\end{tabular}

Sumber: Marshall Hodgson, The Venture of Islam I: Conscience and History in a World Civilization (Jakarta: Paramadina, 2000).

Pada pertengahan periode Sasani akhir dan khilafah awal, dunia berada dalam keadaan spiritual yang merusak kehidupan sosial masyarakatnya. Keserakahan telah menghapus moral serta penindasan telah melumpuhkan mayoritas penduduknya. Bangsa-bangsa peradaban tertua di dunia yang dulunya pernah merdeka dan produktif seperti Assyria, Phunisia dan Mesir, kini tidak berkutik dibawah ancaman dan cengkraman Serigala Romawi. Sementara peradaban Babilonia yang menderita akibat dominasi Persia hanya di bolehkan hidup marginal, semua kekayaan negerinya dieksploitasi untuk memenuhi perbendaharaan para kaisar Persia dan kaki tangannya.

Arab yang letaknya antara Imperium Persia dan Romawi, merupakan sebuah negeri yang menyedihkan pada abad itu. Agama mereka yang sebenarnya merupakan monoteisme paling murni, yakni Agama Nabi Ibrahim telah diselewengkan oleh generasi demi generasi. Ketika manusia melupakan sumber mulia kehidupan batinnya serta disibukkan dengan urusan dunia, seorang Rasul diutus oleh Allah SWT. untuk memperingatkan mereka akan ajaran yang telah mereka abaikan.

Adapun Nabi Muhammad SAW. dalam pandangan umat Islam adalah seorang pahlawan utama. Sedang menurut pandangan para pemikir agama lain dia adalah sang revolusioner, pembangun umat terbesar (Jauzi, 2006: 128). Oleh karena itu tidak patut kita berbicara tentang kepahlawanan tanpa mendahulukan tentang kepahlawanan Muhammad. Sebab tokoh paling berpengaruh sepanjang sejarah manusia adalah Muhammad. Ia adalah satusatunya orang yang berhasil meraih keberhasilan luar biasa baik dalam hal spiritual maupun kemasyarakatan (Hart, 1978: 17).

Gambaran lain tentang bagaimana Muhammad menyelenggarakan kekuasaan politiknya dapat dilihat pada usahanya dalam mengukuhkan sistem 
yang menjamin kebaikan, keadilan, kejujuran bagi semua kalangan tanpa memandang warna kulit, keyakinan maupun ras. Muhammad mengambil langkah-langkah efektif untuk menegakkan kehidupan sosial yang lebih baik. Sehingga bisa membangun kesadaran masyarakat yang semula terbiasa dengan tradisi tidak layak menjadi masyarakat yang menjalani kehidupan yang santun, bertatakrama dan damai.

\section{Biografi Muhammad}

Muhammad bin Abdullah adalah pembawa ajaran agama Islam, dan diyakini oleh umat Muslimin sebagai nabi dan rasul yang terakhir. Menurut biografi yang tercatat oleh ahli sejarah tentang Muhammad, ia disebutkan lahir sekitar tahun $570 \mathrm{M}$ di Makkah dan wafat pada tahun $632 \mathrm{M}$ di Madinah (Hosain, 1995: 27). Kedua kota tersebut terletak di daerah Hijazh, Saudi Arabia. Muhammad lahir di kota Makkah, di bagian Selatan Jazirah Arab, suatu tempat yang ketika itu merupakan daerah paling terbelakang di dunia, jauh dari pusat perdagangan, seni, maupun ilmu pengetahuan. Muhammad dilahirkan di tengah-tengah masyarakat terbelakang yang senang dengan kekerasan dan perang. Ayahnya, meninggal dalam perjalanan dagang di Madinah, ketika Muhammad masih dalam kandungan. Ia meninggalkan harta lima ekor unta, sekawanan biri-biri dan seorang budak perempuan bernama Ummu Aiman yang kemudian mengasuh Nabi (Jauzi, 2006: 101).

Pada saat Muhammad berusia 6 tahun, ibunya Aminah binti Wahab mengajaknya ke Madinah untuk mengunjungi keluarganya serta mengunjungi makam ayahnya (Hosain, 1995: 18). Namun dalam perjalanan pulang, ibunya jatuh sakit. Setelah beberapa hari, Aminah meninggal dunia di Abwa' pada $576 \mathrm{M}$ yang terletak tidak jauh dari Yatsrib, dan dikuburkan di sana. Setelah ibunya meninggal, Muhammad dijaga oleh kakeknya, 'Abd al Muthalib. Setelah kakeknya meninggal pada $578 \mathrm{M}$, ia dijaga oleh pamannya, Abu Thalib. Ketika inilah sekitar tahun $583 \mathrm{M}$ ia diminta menggembala kambingkambingnya di sekitar Makkah dan kerap menemani pamannya dalam urusan dagangnya ke negeri Syam, termasuk Suriah, Lebanon dan Palestina (Jauzi, 2006: 95).

Muhammad menerima wahyu yang pertama pada tahun $610 \mathrm{M}$, dan mulai berdakwah untuk pertamakalinya secara terang-terangan pada tahun 613 M. Tepatnya diangkat menjadi rasul pada malam hari tanggal 17 Ramadan, diriwayatkan Malaikat Jibril datang dan membacakan surah pertama dari Quran yang disampaikan kepada Muhammad, yaitu surah al 'Alaq (Jauzi, 
2006: 95). Selama tiga tahun pertama sejak pengangkatannya sebagai rasul, Muhammad hanya menyebarkan Islam secara terbatas di kalangan teman dekat dan kerabatnya, hal ini untuk mencegah timbulnya reaksi penolakan secara keras kalangan bangsa Arab yang saat itu sudah terasimilasi budayanya dengan tindakan-tindakan amoral. Kebanyakan dari mereka yang percaya dan meyakini ajaran Muhammad pada masa-masa awal adalah para anggota keluarganya serta golongan masyarakat awam yang dekat dengannya di kehidupan seharihari, antara lain Khadijah, Ali bin Abi Thalib, Zaid bin Haritsah dan Bilal bin Rabah (Jauzi, 2006: 101). Kesemua pemeluk Islam pertama itu disebut dengan al Sabiqun al Awwalun/the first Believers.

Penyiksaan yang dialami hampir seluruh pemeluk Islam selama periode itu, mendorong lahirnya gagasan untuk berhijrah ke Habsyah (sekarang Ethiopia) pada tahun $615 \mathrm{M}$. Raja Habsyah, memperbolehkan orang-orang Islam berhijrah ke negaranya dan melindungi mereka dari tekanan penguasa di Makkah. Muhammad sendiri, pada tahun $622 \mathrm{M}$ hijrah ke Yathrib (sekarang Madinah), kota yang berjarak sekitar $320 \mathrm{~km}$ di sebelah utara Makkah.

Demikian kronologi riwayat hidup Muhammad sampai pada wafatnya:

Tahun Peristiwa

569 Wafatnya Abdullah (Ayah Muhammad)

570 Muhammad lahir di Makkah

576 Wafatnya Aminah (Ibu Muhammad)

578 Wafatnya Abdul Muthalib (Kakek Muhammad)

583 Melakukan perjalanan dagang ke Suriah bersama Abu Thalib

595 Bertemu dan Menikah dengan Khadijah

610 Menerima wahyu dan diangkat menjadi Rasul

613 Menyebarkan Islam pada masyarakat Makkah

615 Hijrah ke Habsyah

619 Wafatnya Khadijah dan Abu Thalib

621 Bai'at Aqabah Pertama

622 Bai'at Aqabah Kedua, Hijrah ke Madinah

624 Perang Badar, Pengusiran Bani Qaynuqa dari Madinah

625 Perang Uhud, Pengusiran Bani Nadir

626 Penyerangan ke Suriah (Dumat al Jandal)

627 Perang Khandak, Penghancuran Bani Quraidhah

628 Perjanjian Hudaibiyah, Penghancuran Bani Khaybar

629 Perang Mu'tah

630 Pembukaan kota Makkah, Perang Hunain 
631 Pengepungan Thaif, Menguasai sebagian besar Jazirah Arab

632 Perang Tabuk, Haji Wada', Muhammad wafat

Sumber: Marshall Hodgson, The Venture of Islam I: Conscience and History in a World Civilization (Jakarta: Paramadina, 2000)

Dalam sejarah di Madinah ini, memang banyak terjadi peperangan sebagai upaya kaum Muslimin mempertahankan diri dari serangan musuh. Perjanjian damai dengan berbagai kabilah di sekitar Madinah juga diadakan dengan maksud memperkuat kedudukan Madinah. Pada tahun 9-10 H banyak suku dari pelosok Arab mengutus delegasinya kepada Muhammad untuk menyatakan ketundukan mereka. Persatuan bangsa Arab telah terwujud, peperangan antara suku yang berlangsung sebelumnya telah berubah menjadi persaudaraan seagama. Setelah itu Muhammad kembali ke Madinah untuk mengatur masyarakat yang telah memeluk Islam. Dan pada tahun $632 \mathrm{M}$ tanggal 12 Rabi'ul Awal 11 H Muhammad wafat di rumah istrinya Aisyah.

\section{Sejarah Munculnya Islam Sebagai Entitas Sosial dan Politik}

Selama berabad-abad kehidupan di Semenanjung Arabia berlangsung tanpa pengaturan pemerintahan yang jelas. Persia dan Romawi yang merupakan wilayah tetangga, secara tidak langsung berkuasa atas Semenanjung Arabia dan sangat mempengaruhi kehidupan sosial politik bangsa Arab. Secara sosial politik, bangsa Arab terpecah menjadi berbagai suku, dan sering diantara mereka terjadi perselisihan (Rahman, 2009: 3). Perselisihan antar suku ini, sering berkembang menjadi peperangan yang berlangsung selama bertahuntahun.

Arabia dalam keadaan terbagi, masyarakatnya yang tengah menjadi eksperimen pembentukan politik terancam oleh anarki, kekuasaan kesukuan yang mana sangat mengancam stabilitas pertanian, aktifitas komersial dan ikatan politik. Masyarakatnya merupakan suatu komunitas sosial yang telah terjamah oleh sejumlah pengaruh kerajaan namun tidak disertai dengan sebuah pemerintahan. Arabia sedang berusaha menemukan posisinya dalam dunia Timur Tengah, segala sesuatunya dalam keadaan yang tidak teratur (Jauzi, 2006: 21). Di tempat inilah Muhammad lahir, tumbuh berkembang, menyampaikan al Quran dan menyebarkan Islam.

Masyarakat Arab dari berbagai suku setiap tahunnya datang ke Makkah untuk beziarah ke Baitullah, mereka menjalankan berbagai tradisi keagamaan dalam kunjungan tersebut. Muhammad melihat ini sebagai peluang untuk 
menyebarluaskan ajaran Islam. Di antara mereka yang tertarik dengan ajarannya ialah sekumpulan orang dari Yathrib (Madinah). Mereka menemui Muhammad dan beberapa orang yang telah terlebih dahulu memeluk Islam dari Makkah di suatu tempat bernama Aqabah secara sembunyi-sembunyi. Setelah menganut Islam, mereka lalu bersumpah untuk melindungi para pemeluk Islam dan Muhammad dari kekejaman penduduk Makkah.

Tahun berikutnya $(622 \mathrm{M})$ sekumpulan masyarakat Islam dari Madinah datang lagi ke Makkah, mereka menemui Muhammad di tempat mereka bertemu sebelumnya. Abbas bin Abdul Muthalib, yaitu pamannya yang saat itu belum menganut Islam, turut hadir dalam pertemuan tersebut. Mereka mengundang orang-orang Islam Makkah untuk berhijrah ke Madinah dikarenakan situasi di Makkah yang tidak kondusif bagi keamanan para pemeluk Islam. Muhammad akhirnya menerima ajakan tersebut dan memutuskan berhijrah ke Madinah.

Kondisi penduduk Madinah pada saat itu, terbagi menjadi tiga kelompok, yakni suku Khazraj, suku Aus dan kelompok Yahudi. Kelompok yahudi sendiri terbagi menjadi 3 suku, Qaynuqa, Nadir, Quraidhah. Pada saat itu Khazraj dan Aus selalu berperang karena diadu domba oleh kelompok yahudi. Namun akhirnya mereka bersatu karena sadar telah dihasud oleh yahudi dan merasa bosan dalam berperang.

Pada masa awal kehidupan di Madinah, Muhammad dihadapkan pada situasi yang sangat sulit, kaum muhajirin (masyarakat Muslimin asal Makkah) hidup miskin dan tidak berdaya sebab mereka terpaksa meninggalkan harta benda mereka yang sudah dikuasai orang kafir Quraisy. Sementara itu, orang kafir Quraisy di Makkah mengancam untuk menyerang Madinah. Di Madinah sendiri juga sudah mulai bermunculan dan berkembang kelompok munafik.

Menghadapi kenyataan itu, Muhammad mengambil langkah untuk mengukuhkan negara Islam yang baru didirikan itu secara sosial, politik dan ekonomi. Berbagai langkah utama yang diambil untuk mencapai tujuan tersebut diantaranya, membangun ikatan persaudaraan timbalbalik antara kaum Muhajirin dan Anshar, membuat piagam kebebasan untuk bangsa Yahudi, membuat konstitusi Madinah (dokumen politik perjanjian Muslimin dengan Yahudi).

Di Madinah, pemerintahan (kekhalifahan) Islam diwujudkan di bawah pimpinan Muhammad. Umat Islam bebas beribadah dan bermasyarakat di Madinah, begitupun kaum minoritas Kristen dan Yahudi. Dalam periode 
setelah hijrah ke Madinah, Muhammad sering mendapat serangkaian serangan, teror, ancaman pembunuhan dan peperangan yang ia terima dari penguasa Makkah, akan tetapi semuanya dapat teratasi lebih mudah dengan umat Islam yang saat itu telah bersatu di Madinah. Salah satu hal yang tidak dapat disangkal adalah pertumbuhan dan perkembangan Islam itu bersama dengan pertumbuhan kehidupan sosial dan perkembangan sistem politik yang diilhaminya. Sejak Muhammad melakukan hijrah hingga saat ini, setidaknya Islam sudah terlihat menampilkan dirinya terkait dengan politik (Hosain, 1995: 71). Hijrahnya Muhammad dari Makkah ke Madinah dalam rangka mengemban misinya dari Allah, yakni menciptakan kehidupan masyarakat yang berbudaya tinggi sehingga menghasilkan suatu entitas sosial politik yakni sebuah negara.

\section{Realitas Sosial dan Politik}

Muhammad memberikan sumbangan luar biasa terhadap bangunan filsafat politik dan praktik pemerintahan. Kontribusinya ini menjadi saksi hidup yang membuktikan kebesarannya sebagai negarawan yang genius dan kecakapan yang luar biasa. Bagi masyarakat yang memiliki visi dan pandangan jauh kedepan, setelah memperhatikan sejumlah peristiwa interaksi Muhammad dengan masyarakat Makkah, kepribadiannya dan ajarannya yang menginspirasi, jelaslah Muhammad akan menjadi orang besar dan tidak ada yang mampu menghentikannya. Muhammad pun diyakini akan berkuasa atas bangsa Arab. Berikut peristiwa-peristiwa penting yang terjadi selama Muhammad hidup pada kehidupan sosial masyarakat Makkah-Madinah serta rintangan yang dilalui sehingga bisa menguasai hampir seluruh wilayah Jazirah Arab,

\section{Bai'at Aqabah Pertama Tahun 621 M (Kontrak Politik Pertama Muhammad)}

Bai'at berarti perjanjian atau ikrar bagi penerima dan sanggup memikul atau melaksanakan sesuatu yang dibai'atkan. Bai'at Aqabah (Perjanjian Aqabah) merupakan perjanjian kesetiaan antara Muhammad dan 12 orang Yathrib (suku Khazraj dan suku Aus) yang sedang melakukan perjalanan haji ke Makkah, perjanjian ini berlangsung di kaki bukit Aqabah, Mina (Ibnu Ishaq 2002: 57). Pada masa inilah Islam mulai tersebar di kalangan penduduk Madinah. Salah satu isi perjanjian ini, merujuk pada Ubada Ibnu Shamit, berbunyi, "Kami bersumpah untuk berperang, patuh sepenuhnya pada Rasulullah, baik dalam keadaan senang maupun sengsara, dalam keadaan mudah maupun 
sukar, kami tidak akan mendhalimi siapapun, kami akan jujur kapanpun dan dalam melaksanakan perintah Allah, kami tidak akan pernah takut kepada siapapun atau malu atas cercaan siapapun” (Rahman, 2009: 201). Setelah bai'at pertama ini terlaksana, pengikutnya meminta Muhammad untuk mengirimkan seorang pengajar/pembimbing yang dapat percaya untuk mengajarkan syariat Islam di Madinah. Nabi pun mengutus Mushab bin Umair yang dipercaya untuk menjadi duta besar terbaik pada saat itu.

\section{Bai'at Aqabah Kedua Tahun 622 M (Awal Kehidupan Politik Muhammad)}

Bai'at aqabah ke-2 ini, utusan yang datang adalah 73 laki-laki dan 2 perempuan. Isi perjanjian itu menyatakan, "Kami akan melindungimu sebagaimana kami melindungi anggota keluarga kami sendiri, kendati kami harus bertarung melawan bangsa yang memusuhi, dan kami akan setia bersamamu, bahkan ketika kami harus berperang melawan sanak famili kami sendiri ataupun orang asing". Inilah awal kehidupan politik Muhammad, beliau kini memasuki arena perjuangan baru dengan cara yang berbeda. Setelah bai'at kedua ini terlaksana, Muhammad Hijrah ke Madinah, sebab ia mendapatkan gangguan yang semakin keras dari kaum musyrikin. Beliau dan kaum Musliminin yang lain berhijrah secara sembunyi-sembunyi, agar tidak diketahui oleh kaum musyrikin. Hijrahnya ke Madinah ini merupakan langkah awal dari kehidupan politiknya sebagai seorang pemimpin negara Islam yang masih kecil, yang kemudian diikuti dengan berbagai kejadian, perjanjian dan perang, yang semuanya menjadi saksi atas kebesarannya sebagai negarawan.

\section{Piagam Madinah Tahun 622 M (Konstitusi Pertama di Madinah)}

Piagam Madinah (صحيفة المدينه) juga dikenal dengan sebutan Konstitusi Madinah, merupakan sebuah dokumen yang disusun oleh Muhammad, yang merupakan suatu perjanjian formal antara dirinya dengan semua sukusuku dan kaum-kaum penting di Yathrib pada tahun 622 Masehi. Dokumen tersebut disusun sejelas-jelasnya dengan tujuan utama untuk menghentikan pertentangan sengit antara suku Khazraj dan suku Aus di Madinah. Untuk itu dokumen tersebut menetapkan sejumlah hak-hak dan kewajiban-kewajiban bagi kaum Muslim, kaum Yahudi, dan komunitas penyembah berhala di Madinah. Sehingga membuat mereka menjadi suatu kesatuan komunitas, yang dalam bahasa Arab disebut ummah. Piagam Madinah terdiri dari 47 
pasal yang terdiri dari hal muqaddimah, dilanjutkan oleh halhal seputar pembentukan umat, persatuan seagama, persatuan segenap warga negara, golongan minoritas, tugas warga negara, perlindungan negara, pimpinan negara, politik perdamaian dan penutup. Disinilah kita bisa melihat peran dan fungsi Muhammad sebagai seorang negarawan sekaligus seorang pemimpin negara yang besar dan berkualitas sepanjang sejarah peradaban manusia, disamping posisinya selaku seorang Nabi dan Rasul secara keagamaan.

\section{Perang Badar dan Pengusiran Bani Qaynuqa (624 M)}

Perang Badar ini merupakan perang darah pertama dan kemenangan kaum Muslimin (Muhammad, Hamzah, Ali, ) terhadap kaum kafir Quraisy (Abu Jahal). Lokasinya di Kota Badar (Madinah). Pasukan kecil kaum Muslimin yang berjumlah 313 orang bertempur menghadapi pasukan Quraisy dari Makkah yang berjumlah 1.000 orang. Meskipun demikian, Perang Badar adalah perang skala besar pertama yang terjadi antara kedua kekuatan itu. Saat inilah orang-orang Yahudi bani Qaynuqa keluar dari Madinah. Kemenangan kaum Muslimin juga memperlihatkan kepada suku-suku Arab lainnya bahwa suatu kekuatan baru telah bangkit di Arabia, serta memperkokoh otoritas Muhammad sebagai pemimpin atas berbagai golongan masyarakat Madinah yang sebelumnya sering bertikai. Berbagai suku Arab mulai memeluk agama Islam dan membangun persekutuan dengan kaum Muslimin di Madinah. Dengan demikian, ekspansi agama Islam pun dimulai. Kekalahan Quraisy dalam Perang Badar menyebabkan mereka bersumpah untuk membalas dendam, dan hal ini terjadi sekitar setahun kemudian dalam Perang Uhud.

\section{Perang Uhud dan Pengusiran Bani Nadir (625 M)}

Perang Uhud adalah perang yang pecah antara kaum Musliminin dan kaum kafir Quraisy pada tanggal 22 Maret 625 M/7 Syawal 3 H. Perang ini terjadi kurang lebih setahun lebih seminggu setelah Perang Badar. Tentara Islam berjumlah 700 orang sedangkan tentara kafir berjumlah 3.000 orang. Tentara Islam dipimpin langsung oleh Rasulullah sedangkan tentara kafir dipimpin oleh Abu Sufyan. Disebut Perang Uhud karena terjadi di dekat bukit Uhud yang terletak 4 mil dari Masjid Nabawi dan mempunyai ketinggian 1000 kaki dari permukaan tanah dengan panjang 5 mil. Pada perang ini, kaum kafir Quraisy gagal menekan kaum Muslimin Madinah walaupun mereka meraih kemenangan, perang ini berlokasi di depan Gunung Uhud (Madinah). Dikomandani oleh Muhammad dari pihak Muslimin dan Abu Sofyan dari 
pihak persekutuan pimpinan Makkah. Pada saat itu orang-orang Yahudi bani Nadir diusir dari Madinah.

\section{Perang Khandak dan Penghancuran Bani Quraidhah (627 M)}

Perang ini dinamakan juga sebagai perang Ahzab, perang Konfederasi, perang Madinah, terjadi pada bulan Syawal tahun ke-5 Hijriyah/627 M. Perang ini dipelopori oleh pasukan gabungan antara kaum kafir Quraisy dengan kaum Yahudi bani Nadir. Penduduk Makkah mengepung Madinah, dan orang-orang Yahudi bani Quraidhah dibunuh massal. Pasukan Yahudi yang membelot bersama Abdullah bin Ubay termasuk bani Nadir (kecuali bani Quraidhah) diusir ke luar kota Madinah. Mereka menuju Khaibar. Mereka bergabung dengan masyarakat Makkah menyusun kekuatan untuk menyerang Madinah. Setelah sebulan pengepungan, angin dan badai pun turun dengan kencangnya dan memporak-porandakan seluruh kemah dan perlengkapan mereka. Akhirnya mereka pun menghentikan pengepungan dan kembali ke negeri masing-masing tanpa hasil (Khoiriyah, 2012: 91).

\section{Perjanjian Hudaibiyah dan Penghancuran Bani Khaybar (628 M)}

Perjanjian Hudaibiyyah adalah sebuah perjanjian yang diadakan di sebuah tempat di antara Madinah dan Makkah pada bulan Maret $628 \mathrm{M} /$ Dhulqa'dah $6 \mathrm{H}$. Muhammad mencoba agar tidak terjadi pertumpahan darah di Makkah, karena Makkah adalah tempat suci. Akhirnya kaum Muslimin menyetujui langkah Nabi Muhammad, bahwa jalur diplomasi lebih baik daripada berperang. Garis besar Perjanjian Hudaibiyah (Haekal, 2007: 121) berisi:

"Dengan nama Tuhan, ini perjanjian antara Muhammad dan Suhail bin 'Amru (perwakilan Quraisy). Tidak ada peperangan dalam jangka waktu sepuluh tahun, siapapun yang ingin mengikuti Muhammad diperbolehkan secara bebas dan siapapun yang ingin mengikuti Quraisy, diperbolehkan secara bebas".

Perjanjian ini merupakan kesepakatan damai antara Muhammad dan kaum kafir Quraisy, perjanjian ini tidak hanya menciptakan perdamaian, tapi juga membuka jalan bagi terciptanya kebebasan berkomunikasi dan berdiskusi diantara dua belah pihak. Perjanjian Hudaibiyah mengubah jalan sejarah Islam secara keseluruhan sehingga kemenangan atas Makkah tinggal menunggu waktu, ini merupakan kemenangan politik terbesar Muhammad dan membuka jalan bagi menyebarnya Islam serta pengaruh politik dan 
spiritual Muhammad di Jazirah Arab. Pada masa ini, orang-orang Yahudi Khaybar ditundukkan.

\section{Perang Mu'tah $(629 \mathrm{M})$}

Setelah Perjanjian Hudaibiyyah disepakati, Rasullulah mengirimkan surat-surat dakwah sekaligus berdiplomasi kepada para penguasa negeri yg berbatasan dengan Jazirah Arab. Pada Tahun 7 H atau 628 M, Rasulullah menugaskan al Harits bin 'Umair untuk mengirimkan surat dakwah kepada Gubernur Syam (Irak) bernama Hanits bin Abi Syamr al Ghassani yg baru diangkat oleh Kekaisaran Romawi. Dalam Perjalanan, di daerah sekitar Mut'ah, Harits bin 'Umair dibunuh oleh penguasa setempat bernama Syurahbil bin 'Amr al Ghassani pemimpin dari suku Ghassaniyah, pada waktu itu yang berkuasa di wilayah Palestina dan sekitarnya (Haekal, 2007: 127). Perang Mu'tah terjadi pada $629 \mathrm{M}$ atau 5 Jumadil Awal $8 \mathrm{H}$ dekat kampung yang bernama Mu'tah, antara pasukan Khulafaur Rasyidin yang dikirim oleh

Nabi Muhammad dan tentara Kekaisaran Romawi Timur, Bashra (Haekal, 2007: 129).

\section{Pembukaan Kota Makkah (630 M)}

Pada 10 Ramadlan tahun $8 \mathrm{H}$ Muhammad ke Madinah, Muhammad berangkat ke Makkah dengan membawa pasukan Muslimin kurang lebih 10.000 orang, saat itu ia bermaksud untuk menaklukkan kota Makkah dan menyatukan para penduduk kota Makkah dan Madinah (Haekal, 2007: 131). Penguasa Makkah yang tidak memiliki pertahanan yang memadai kemudian setuju untuk menyerahkan kota Makkah tanpa perlawanan, dengan syarat akan diserahkan tahun berikutnya. Muhammad pun menyetujuinya. Pada tahun berikutnya ketika ia kembali, ia telah berhasil mempersatukan Makkah dan Madinah, dan lebih luas lagi menyebarluaskan Islam ke seluruh Jazirah Arab. Muhammad memimpin umat Islam menunaikan ibadah haji, memusnahkan semua berhala yang ada di sekeliling Ka'bah, dan kemudian memberikan amnesti umum dan menegakkan peraturan Islam di kota Makkah.

\section{Pengepungan Thaif dan Menguasai Jazirah Arab (631 M)}

Sedikit sekali yang diketahui mengenai jalannya pengepungan ini. Namun, dalam pengepungan ini diketahui bahwa Abu Sufyan, yang bertempur di pihak Muslimin, kehilangan salah satu matanya. Sekalipun pengepungan ini berakhir dengan kegagalan, tidak berapa lama kemudian 
setelah pengepungan ini para penduduk Tha' if (Bani Tsaqif) akhirnya masuk Islam, tepatnya setelah perang Tabuk.

\section{Perang Tabuk (632 M)}

Perang Tabuk adalah perang yang dilakukan umat Islam dengan pimpinan Muhammad pada $630 \mathrm{M}$ atau $9 \mathrm{H}$, ke Tabuk, yang sekarang terletak di wilayah Saudi Arabia di barat laut. Pasukan Islam gagal mengalahkan pasukan Bizantium (Romawi Timur) dalam perang Mu'tah. Banyak yang menganggap hal ini sebagai tanda melemahnya kekuatan umat Islam, dan memancing beberapa kabilah Arab menyerang umat Muslimin di Madinah. Perang ini untuk melindungi umat Islam di Madinah, Muhammad memutuskan untuk melakukan aksi preventif, dan menyiapkan pasukan. Hal ini disulitkan dengan adanya kelaparan di tanah Arab dan kurangnya kas umat Musliminin. Namun, Muhammad berhasil mengumpulkan pasukan yang terdiri dari 30.000 orang, jumlah pasukan terbanyak yang pernah dimiliki umat Islam.

Setelah sampai di Tabuk, umat Islam tidak menemukan pasukan Bizantium ataupun sekutunya. Menurut sumber-sumber ilmuwan sejarah Muslim, mereka melarikan diri ke utara setelah mendengar kedatangannya pasukan Muhammad. Pasukan Muslimin berada di Tabuk selama 10 hari. Perang ini dimanfaatkan Muhammad untuk mengunjungi kabilah-kabilah yang ada di sekitar Tabuk. Hasilnya, banyak kabilah Arab yang sejak itu tidak lagi mematuhi Kekaisaran Bizantium, dan berpihak kepada Muhammad dan umat Islam. Umat Islam maupun Kekaisaran Bizantium tidak menderita korban dari peristiwa ini, karena perang tidak pernah terjadi.

\section{Simpulan}

Periode inilah (610-1258 M) para ahli sejarah menyebutnya dengan Periode Klasik. Dimana Muhammad mampu mengelola bangsa yang awalnya egoistis, terbelakang dan terpecah belah oleh sentimen kesukuan, menjadi bangsa yang maju dalam bidang ekonomi, kebudayaan dan kemiliteran. Bahkan seorang Muhammad sanggup mengalahkan pasukan Romawi yang saat itu merupakan kekuatan militer terdepan di dunia. Menurut hemat penulis, periode dakwah Muhammad terbagi menjadi dua masa, periode Makkah kurang lebih selama 12 tahun, dan periode Madinah berjalan kurang lebih 10 tahun. Dalam waktu kurang lebih satu dasawarsa inilah, semua kekuatan yang semula terpecah berhasil dipersatukan berkat kemampuan diplomasi politik Muhammad. Bahkan tanpa 
perslisihan, mayoritas menyepakati Muhammad sebagai penguasa Jazirah Arab dan menjadikannya orang pertama yang berhasil mempersatukan semua suku Arab dan memberikan kedamaian serta keamanan kepada mereka. Inilah wujud yang lebih disebabkan oleh keterampilan politis dan manuver diplomatisnya dibandingkan kelihaian militer dan kesuksesan perangnya.

\section{Daftar Pustaka}

Haekal, Husain. 2007. Hayat Muhammad (Sejarah Hidup Muhammad). Terjemahan oleh: Ali Audah. Bogor: Litera AntarNusa.

Hart, Michael. 1978. The 100. Amerika Serikat: Carol Publishing.

Hodgson, Marshall G.S. 2002. The Venture of Islam I: Conscience and History in a World Civilization (Iman dan Sejarah dalam Peradaban Dunia: Masa Klasik Islam). terjemahan oleh: Mulyadhi Kartanegara. Jakarta: Paramadina.

Hosain, Safdar. 1995. The Early History of Islam I. Delhi: LP Publication.

Ibnu Ishaq, Muhammad. 2002. The Life of Muhammad (Sirah Ibnu Ishaq: Buku Tertua tentang Sejarah Nabi Muhammad) Buku ke-2. Terjemahan oleh: Dewi Candraningrum. Surakarta: UMS Press.

Jauzi, Ibnu. 2006. Al Wafa bi Ahwal alMushthafa (Kesempumaan Pribadi Nabi Muhammad). Terjemahan oleh: Mahfud Hidayat. Jakarta: Pustaka al Kautsar.

Khoiriyah. 2012. Reorientasi Wawasan Sejarah Islam Dari Arab Sebelum Islam Hingga Dinasti-Dinasti Islam. Yogyakarta: Teras.

Rahman, Afzalur. 2009. Encyclopedia of Seerah (Muhammad Sebagai Negarawan). Terjemahan oleh: Taufik Rahman. Bandung: Pelangi Mizan. 